\title{
Cerebral neoplastic angioendotheleosis complicated by hypercalcaemia
}

\author{
A.S. Wierzbicki ${ }^{1}$, J.M. Gibbs ${ }^{2}$, H.G.W. Lidov ${ }^{3}$, Y. Lolin ${ }^{1}$ and P.K. Thomas ${ }^{4}$ \\ Departments of ${ }^{1}$ Chemical Pathology, ${ }^{2}$ Neurology and ${ }^{3}$ Neuropathology, National Hospitals for Nervous \\ Diseases, Queen Square, London WC1N $3 B G$, and ${ }^{4}$ University Department of Clinical Neurology, Institute \\ of Neurology, Queen Square, London WCIN 3BG, UK
}

\begin{abstract}
Summary: This is a case report of a 67 year old man who presented with a fluctuating level of consciousness and myoclonic jerks caused in part by hypercalcaemia. The diagnosis of cerebral neoplastic angioendotheleosis was only made later on brain biopsy and is the first report of the occurrence of hypercalcaemia in neoplastic angioendotheleosis.
\end{abstract}

\section{Introduction}

The condition known as neoplastic angioendotheleosis was first described in 1959 by Pfleger and Tappeinner. ${ }^{1}$ The disease usually presents with a nonspecific encephalopathic illness or with skin involvement ${ }^{2}$ without gross metabolic disturbances. We report a patient in whom a typical neurological illness was complicated by hypercalcaemia.

\section{Case report}

A 67 year old man presented to another hospital with a 4-week history of pain in his legs, difficulty in passing urine and an unsteady gait. Sensory loss was noted over the L5 to S2 dermatomes on his left leg and mild intellectual deterioration was suspected. All biochemical investigations were normal at this stage.

Three months later he developed urinary retention and the intellectual deterioration was marked. On examination he now looked parkinsonian, had bilateral grasp reflexes and extensor plantars but had no focal neurological signs. Subsequently his . conscious level began to fluctuate and he developed generalized multifocal myoclonus.

On admission to the National Hospitals he was unconscious, responding only to pain; generalized myoclonic jerks were noted. He had quadriceps muscle wasting but knee and ankle reflexes were preserved. Other neurological signs were unchanged.

After initial investigations had shown hypercal-

Correspondence: A.S. Wierzbicki, M.A., B.M., B.Ch., Wolfson College, Oxford OX2 6UD, UK.

Accepted: 22 October 1990 caemia he was treated with forced diuresis and corticosteroids. The myoclonus resolved and there was partial improvement in his conscious level up to the point of understanding simple commands. However, he remained mostly disorientated with periods of agitation and paranoia. Some seizures occurred, usually with a focal onset in the right arm and distinguished by headturning to the right.

Investigations to date had not reached a diagnosis so a right frontal brain biopsy was performed. Histology diagnosed angioendotheleosis and the patient was transferred for radiotherapy and chemotherapy. His condition deteriorated and he died after only one session of radiotherapy had been completed.

\section{Investigations}

There was a mild normocytic normochromic anaemia (haemoglobin $11.3 \mathrm{~g} / \mathrm{dl}$ ), and a raised ESR $(30-59 \mathrm{~mm} / \mathrm{h})$. Bone marrow examination was normal. Cerebrospinal fluid (CSF) proteinosis was noted $(140 \mathrm{~g} / \mathrm{dl})$ and there was a slight lymphocytosis $\left(5 \times 10^{9} / 1\right)$.

On admission there was marked hypercalcaemia (corrected for albumin of $3.73 \mathrm{mmol} / \mathrm{l}$; albumin $31 \mathrm{~g} / \mathrm{l})$, low inorganic phosphate $(0.70 \mathrm{mmol} / \mathrm{l})$, hypernatraemia $(158 \mathrm{mmol} / \mathrm{l})$, hypokalaemia $(2.10 \mathrm{mmol} / \mathrm{l})$ and a slightly raised blood urea (10 mmol/l).

After treatment and rehydration, the electrolytes returned to normal over 8 days. The hypercalcaemia alone recurred after 14 days suggesting other causes besides dehydration were involved. Urinary calcium $(5.3 \mathrm{mmol} / \mathrm{l})$, inorganic phosphate $(14 \mathrm{mmol} / \mathrm{l})$ and the calcium:creatinine ratio were normal (0.023). 
Further investigations excluded paraproteinaemia and systemic or meningeal sarcoidosis [CSF angiotensin converting enzyme (ACE) $<2 \mathrm{kU} / \mathrm{l}$; serum $28 \mathrm{kU} / \mathrm{l}$. Reference limits $<4,<45 \mathrm{kU} / \mathrm{l}$, respectively]. Serum cortisol levels $(310 \mathrm{mmol} / \mathrm{l}), \mathrm{n}$ and c-terminal parathyroid hormone (PTH) $(<40$ $\mathrm{pg} / \mathrm{l})$ were normal and 25-hydroxycholecalciferol levels $(25-\mathrm{HCC})(14 \mathrm{ng} / \mathrm{l})$ were borderline low (reference limits 14-30 ng/l). However, serum alkaline phosphatase was raised at $359 \mathrm{kU} / 1$ with a raised bone isoform fraction $(120 \mathrm{U} / \mathrm{ml}$; limit $75 \mathrm{U} /$ $\mathrm{ml}$ ) and normal liver isoform fraction $(50 \mathrm{U} / \mathrm{ml}$; limit $55 \mathrm{U} / \mathrm{ml}$ ) in the absence of other hepatic function derangements. The alkaline phosphatase was principally the bone isoform $(270 \mathrm{kU} / \mathrm{l})$.

Serology, including human $T$ cell leukaemia virus type 1 (HTLV1) and human immunodeficiency virus (HIV) titres, was unremarkable.

Skeletal radiology and bone scintigraphy were normal. Computed tomographic and magnetic resonance imaging scans showed generalized cerebral atrophy representative of small vessel disease.

Histopathology: the full thickness cerebral and meningeal biopsy was stained with haematoxylin and eosin (H\&E), haematoxylin-van Gieson, reticulin and immunocytochemical stains. Many of the smaller cortical blood vessels and some meningeal vessels were filled with abnormal large bizarre malignant leucocytes (Figure 1). Immunocytochemical stains (leucocyte common antigen - LCA, and a T\&B cell marker panel) showed that these cells were positive for B cell markers (immunoglobulin, CD25, UCH L-26), weakly reactive for LCA but not for $T$ cell or epithelial markers (Figure 2). Morphological appearances were consistent with neoplastic angioendotheleosis of an immunological B cell phenotype. After death, a necropsy was not performed.

\section{Discussion}

Neoplastic angioendotheleosis (NAE) is a rare tumour affecting ectodermal tissues whose cell of origin is disputed. Recent evidence has favoured a lymphomatous origin ${ }^{3,4}$ over an endothelial one. ${ }^{5}$ Metabolic abnormalities are rare having only been seen in a case of protein losing enteropathy associated with B-cell NAE. ${ }^{6}$

The patient presented principally with a fluctuating encephalopathy due probably to central NAE, compounded by hypercalcaemia but with features of cauda equina and spinal cord involvement. The previously unsuspected diagnosis was only finally made on brain biopsy. The malignant cells were immunologically of B cell phenotype. Hypercalcaemia occurs in 1.8-3\% of lymphomas especially those of large cell morphology or associated with human $T$ cell leukaemia virus type 1 (HTLV1) infection. ${ }^{4}$

The mechanism of hypercalcaemia remains obscure but abnormal hydroxycholecalciferol metabolism, ${ }^{7}$ lymphokines, prostaglandins ${ }^{8}$ and aô tumour PTH-like factor' ${ }^{9}$ are known to be involved.? This patient had a low serum PTH activity, normalo․ 25-HCC, low phosphate and raised bone alkaline phosphatase, implying a role for PTH-like factors. However, it was not possible to measure urinary cyclic AMP levels. There is no current assay for tumour PTH and it does not immunologically

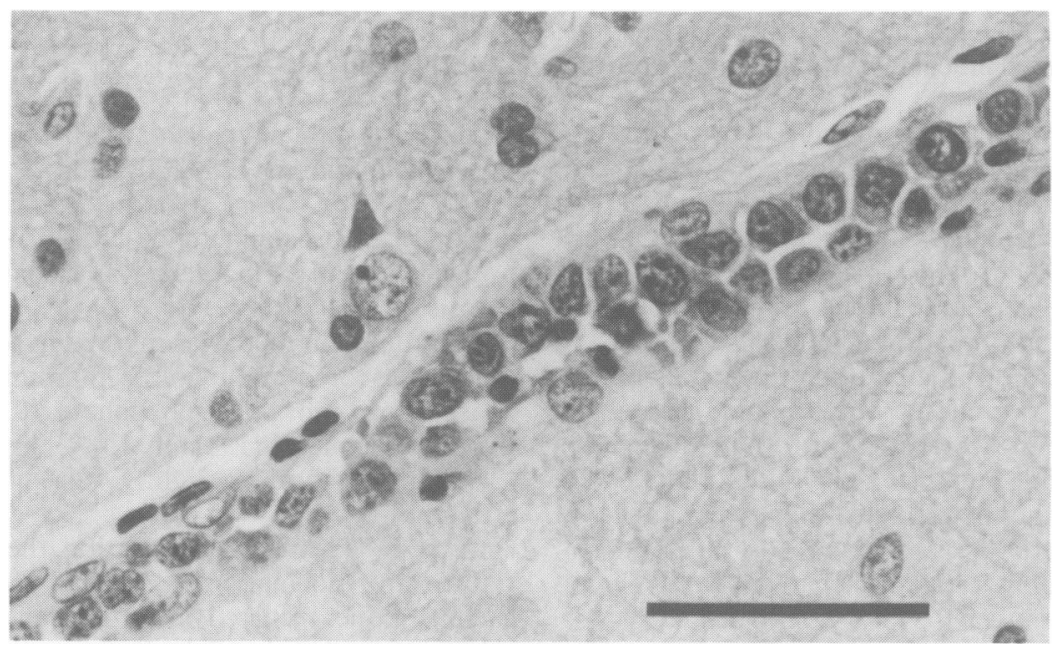

Figure 1 Intravascular neoplastic cells. The large nuclei with abundant chromatin, prominent multiple nucleoli and scant cytoplasm are characteristic of lymphoma. Note the single intravascular mitotic figure in the centre of the field. $\mathrm{H} \& \mathrm{E}$, scale bar $=50 \mu \mathrm{m}$. 


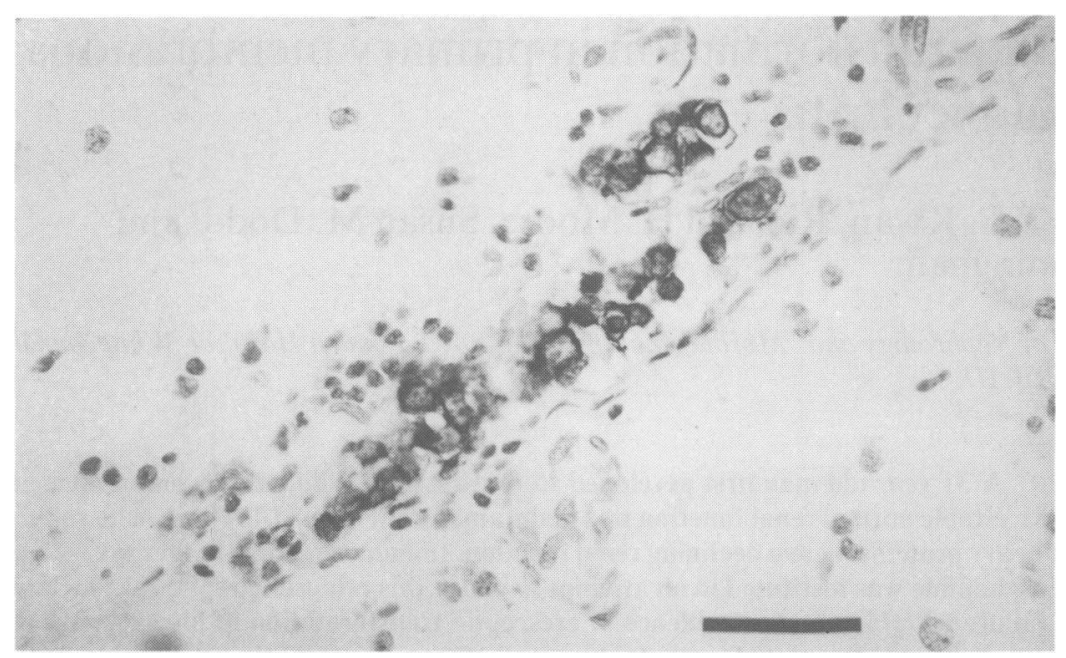

Figure 2 Intravascular neoplastic cells immunoreactive for the B cell marker UCH L-26. Scale bar $=50 \mu \mathrm{m}$.

crossreact with parathyroid PTH (as detected by radioimmunoassay). ${ }^{9}$

The immunocytochemistry in this case strengthens the evidence that NAE is a form of lymphoid neoplasia and should be called intravascular lymphomatosis' ${ }^{3}$ The biochemical findings in this case show that, like other lymphomas, it can be complicated by significant hypercalcaemia.

\section{References}

1. Pfleger, L. \& Tappeinner, J. Zur Kennitis der Systemisierten Endotheliomatose der Cutanen Blutgerfasse. Haytargt 1959, 10: 359-363.

2. Brew, B.J., O'Sullivan, D.J., Darveniza, P. et al. Neoplastic angioendotheleosis. Clin Exp Neurol 1987, 23: 119-126.

3. Wick, M.R., Mills, S.E., Scheitbauer, B.W. et al. Reassessment of malignant 'angioendotheliomatosis'. Evidence in favour of its reclassification as 'intravascular lymphomatosis'. Am J Surg Pathol 1985, 85: 247-248.

4. Sheibani, K., Battifora, H., Winberg, C.D. et al. Further evidence that malignant angioendotheleosis is an angiotropic large cell lymphoma. $N$ Engl J Med 1986, 314: 943-948.

5. Kitzgawa, M., Matsubara, O., Song, S.U. et al. Neoplastic angioendotheleosis: immunohistochemical and electronmicroscopic findings in three cases. Cancer 1985, 56: 1134-1137.

\section{Acknowledgements}

We would like to thank Dr C.H. Hawkes for referring the case, Mr N. Grant for performing the brain biopsy, Professor P.G. Isaacson for the monoclonal antibody UCH L-26 and Mrs P. Jaeger and Ms H. Ayling for preparing the microscope slides.

6. Al-Izzi, M.S., Sidhu, P.S., Garside, P.J. \& Menai-Williams, R. Angiotropic large cell lymphoma (angioendotheliomatosis) presenting with protein losing enteropathy. Postgrad Med J 1988, 64: 313-314.

7. Breslau, N.A., McGuire, J.L., Zerwekh, J.E., Frankel, E.P. \& Pak, C.Y. Hypercalcemia associated with increased serum calciferol levels in three patients with lymphoma. Ann Intern Med 1984, 100: 1-7.

8. Mundy, G.R. The pathogenesis of hypercalcaemia of cancer. Clin Endocrinol Metab 1985, 23: 705-714.

9. Broadus, A.E., Mangin, M., Kyoji, I. et al. Humoral hypercalcemia of cancer. $N$ Engl J Med 1988, 319: 556-563. 